\title{
'The troubles of collecting': William Henry Harvey and the practicalities of natural-history collecting in Britain's nineteenth-century world
}

\author{
John McAleer* \\ Department of History, University of Southampton \\ *Corresponding author: John McAleer, Email: j.mcaleer@soton.ac.uk
}

\begin{abstract}
In recent decades, historians have become increasingly interested in the logistical challenges and difficulties encountered by those responsible for the collection, preservation and safe transport of specimens from the field to the museum or laboratory. This article builds on this trend by looking beyond apparent successes to consider the practices and practicalities of shipboard travel and maritime and coastal collecting activities. The discussion focuses on the example of William Henry Harvey, who travelled to Australia in pursuit of cryptogams - non-flowering plants like mosses, lichens and algae - in 1853. In his private correspondence to family and friends, Harvey offered insights into the challenges and obstacles faced by all collectors in the period. His experiences were fundamentally shaped by the material culture, embodied knowledge and physical constraints he encountered on the way. On one level, shipboard and onshore collecting activities were facilitated by the connections forged by new technologies and Britain's global empire. But they also depended on specific contexts and relied on local agents and actors, as well as on the physical and technical facilities (and limitations) of those doing the collecting. The examples of Harvey and others shed light on the real, 'lived' experiences of individual collectors, the difficulties and challenges they encountered in amassing their collections, and the networks of people on which they relied.
\end{abstract}

William Harvey found what he called 'white ants' troublesome. In Ceylon, as soon as the lamps were put on the table in the evening to assist the botanist in his labours of cataloguing, preserving and storing, these insects disrupted his research by flying into my bottles' and becoming 'immortalised in spirits'. ${ }^{1}$ In light of the other challenges he faced, this was a minor inconvenience for Harvey as he travelled from the relatively salubrious surroundings of Trinity College in Dublin (TCD) to the distant shores of Britain's expanding Australasian empire. ${ }^{2}$ There were undoubtedly more substantial obstacles standing in the way of bringing Harvey's hard-won harvest of natural-history specimens safely back to his rooms in Dublin. But the termites, or white ants, and their ignominious fate - drowned and preserved in alcohol for the perusal of curious Victorian naturalists -

\footnotetext{
${ }^{1}$ William Henry Harvey (hereafter WHH) to his brother, Reuben Harvey (hereafter RH), 20 November 1853, Department of Manuscripts and Archives, Trinity College Library, Trinity College Dublin (hereafter TCD), MS 3640/6.

${ }^{2}$ Recently, however, scholars have begun to pay more attention to the ubiquity of white ants across the British Empire and the fundamental role of these non-human actors in shaping British colonial power. See Rohan Deb Roy, 'White ants, empire, and entomo-politics in South Asia', Historical Journal (2020) 63(2), pp. 411-36. 
alert us to some of the practical challenges and logistical problems encountered by natural-history collectors and other naturalists in the eighteenth and nineteenth centuries as they travelled around the world in search of the specimens and data that would expand the horizons of their disciplines.

Until recently, historians tended to focus on the results of the collecting process - the insights acquired in those college laboratories and elsewhere - without much concern for the difficulties encountered by those responsible for the collection, preservation and safe transport of specimens from the field to the museum, laboratory or university. As Jim Endersby noted, comparatively few of them looked 'in any detail at the day-to-day work of naturalists'. ${ }^{3}$ The 'craft and social history of scientific collecting' were relatively neglected. ${ }^{4}$ As David Igler has remarked, historians privileged 'the end results of scientific and exploratory inquiry, while too often neglecting the naturalist's mental progression that begins with questions'. ${ }^{5}$ Narratives of travel, exploration and collecting compounded this by invariably exalting the heroic efforts of the individual to gather, assemble and record in the name of advancing scientific knowledge and understanding. In recent decades, however, scholars have increasingly challenged this approach by focusing on the logistics, practicalities and variety of people involved in natural-history collecting practices. In doing so, they have built up a much richer picture of the circumstances in which such collecting took place. Jim Endersby has turned our attention, for example, to the 'complex craft activity' that was nineteenth-century collecting, whose practices required 'skills that took time and effort to master'. ${ }^{6}$ Several contributions to Arthur MacGregor's edited volume Naturalists in the Field approach collecting practices from curatorial and material perspectives to focus on the supposedly mundane, everyday and repetitive aspects of collecting'. ${ }^{7}$ And Anne Secord has exposed the blurred boundaries between cabinet and fieldwork. ${ }^{8}$ In a similar vein, the insightful work of Sarah Easterby-Smith has emphasized the 'contingent, negotiated and situated' nature of scientific endeavours in the age of sail, and the need to pay 'close contextual attention to certain individuals and particular circumstances'. "Eighteenth- and nineteenth-century diaries, journals and letters are replete with information about the movement of naturalhistory specimens, enabling us to reconstruct in detail the networks of collectors and collaborators involved. ${ }^{10}$ But we know a great deal less about the logistical realities involved in collecting and transporting this material. The movement of objects - the 'mundane

\footnotetext{
${ }^{3}$ Jim Endersby, Imperial Nature: Joseph Hooker and the Practices of Victorian Science, Chicago: The University of Chicago Press, 2008, p. 54.

${ }^{4}$ Robert E. Kohler, All Creatures: Naturalists, Collectors, and Biodiversity, 1850-1950, Princeton, NJ: Princeton University Press, 2006, p. 2.

${ }^{5}$ David Igler, 'The questions they asked: Joseph Banks and naturalists in the Pacific Ocean', Journal for Maritime Research (2019) 21(1-2), pp. 62-75, 64.

${ }^{6}$ Endersby, op. cit. (3), p. 54.

${ }^{7}$ Arthur MacGregor (ed.), Naturalists in the Field: Collecting, Recording and Preserving the Natural World from the Fifteenth to the Twenty-First Century, Leiden: Brill, 2018; quote from John McAleer, 'Review of Arthur MacGregor (ed.), Naturalists in the Field: Collecting, Recording and Preserving the Natural World from the Fifteenth to the Twenty-First Century', Archives of Natural History (2019) 46(2), pp. 362-3, 363.

${ }^{8}$ Anne Secord, 'Specimens of observations: Edward Hobson's Musci Britannici', in Liba Taub, Joshua Nall and Frances Willmoth (eds.), The Whipple Museum of the History of Science: Objects and Investigations to Celebrate the 75th Anniversary of R.S. Whipple's Gift to the University of Cambridge, Cambridge: Cambridge University Press, 2019, pp. 101-18, 102.

9 Sarah Easterby-Smith, 'Recalcitrant seeds: material culture and the global history of science', Past \& Present (2019) 242, issue supplement 14, pp. 215-42, 219, 221.

${ }^{10}$ See, for example, Anne Secord, 'Corresponding interests: artisans and gentlemen in natural history exchange networks', BJHS (1994) 27(4), pp. 383-408; Mark V. Barrow, A Passion for Birds: American Ornithology after Audubon, Princeton, NJ: Princeton University Press, 1998, pp. $24-7$.
} 
aspects of travel and transport' and 'the mechanisms by which these things moved' around the globe - are, as Jon Stobart points out, issues of key importance to historians, which are now attracting sustained attention. ${ }^{11}$ This article contributes to this ongoing scholarly endeavour. ${ }^{12}$

By focusing primarily on the collecting activities of William Harvey on an expedition to Australia in pursuit of algae and other plants in 1853, this article looks beyond apparent successes, to focus on the failures and travails, the frustrations and difficulties, the disasters and disappointments. ${ }^{13}$ It considers the catastrophic, but also the mundane and the downright tedious. It explores the relationship between embodied forms of knowledge production - like the act of collecting specimens - and material considerations and material culture. The discussion sheds particular light on natural-history collecting undertaken along the maritime routes of Britain's burgeoning nineteenth-century empire. Harvey assured his sister, writing to her from his cabin in the Ripon as he steamed across the Mediterranean, that only exotic plants and specimens interested him and that he did not intend 'to collect anything till I have passed the isthmus' of Suez. ${ }^{14}$

William Harvey was born in 1811 in Limerick, where his father was a Quaker merchant. ${ }^{15}$ When he embarked for the Antipodes, he was curator of the university herbarium at Trinity College Dublin, and professor of botany to the Royal Dublin Society. Harvey's example offers a useful focus because he left substantial archival records, in contrast to many of those engaged in natural-history pursuits in the nineteenth century. While his various professional positions generated extensive correspondence and left significant archival evidence, this article uses the letters relating to his trip to Australia, via the Mediterranean, sent to his sister, niece and brother - as well as some correspondence with professional contacts, like Asa Gray at Harvard and William Hooker, the director of the Royal Botanic Gardens at Kew. ${ }^{16}$ In these letters, Harvey not only demonstrates his interest in cryptogams - non-flowering plants like lichens, mosses and algae-but also offers insights into the range of knowledge and expertise required to collect such specimens. ${ }^{17}$ In his private correspondence to his family and friends, Harvey offered an insight into some of the practical challenges and obstacles faced by all collectors in the period. His hybrid status as a herbarium keeper and an independent collector at one

\footnotetext{
${ }^{11}$ Jon Stobart, 'Magnificent and mundane: transporting people and goods to the country house, c.1730-1800', in Stobart (ed.), Travel and the British Country House: Cultures, Critiques and Consumption in the Long Eighteenth Century, Manchester: Manchester University Press, 2017, pp. 168-87, 169. See, for example, Luke Keogh, The Wardian Case: How a Simple Box Moved Plants and Changed the World, Chicago: The University of Chicago Press, 2020.

${ }^{12}$ In addition to the works cited above, other notable examples include Jane Camerini, 'Remains of the day: early Victorians in the field', in Bernard V. Lightman (ed.), Victorian Science in Context, Chicago: The University of Chicago Press, 1997, pp. 354-77; Anne Larsen, 'Equipment for the field', in Nicholas Jardine, James A. Secord and Emma C. Spary (eds.), Cultures of Natural History, Cambridge: Cambridge University Press, 1996, pp. 358-77; Simon J. Knell, The Culture of English Geology, 1815-1851: A Science Revealed through Its Collecting, Farnham: Ashgate, 2000; Matthew Laubacher, 'Cultures of collection in late nineteenth century American natural history', unpublished PhD thesis, Arizona State University, 2011.

${ }^{13}$ For a similar emphasis on the 'history of failure' see Easterby-Smith, op. cit. (9), p. 241.

${ }^{14}$ WHH to his sister, Mrs Hannah H. Todhunter (hereafter HHT), 10 August 1853, TCD, MS 3640/1.

${ }^{15}$ Details of Harvey's life are drawn from E. Charles Nelson, 'Harvey, William Henry (1811-1866), botanist', Oxford Dictionary of National Biography (2012), at www.oxforddnb.com/view/10.1093/ref:odnb/9780198614128. 001.0001/odnb-9780198614128-e-12533 (accessed 14 June 2019).

${ }^{16}$ Harvey nominated his sister, Hannah Todhunter, to be his 'principal correspondent', through which many of his other contacts would hear news of his travels and exploits. See WHH to Jane Gray, 30 June 1853, in Lydia Fisher (ed.), Memoir of W.H. Harvey, M.D., F.R.S., London: Bell and Daldy, 1869, p. 243.

${ }^{17}$ This approach was taken by the editor of Harvey's Memoir - believed to be his cousin, Lydia Fisher - who recognized that Harvey's character and devotion to his 'vocation' as a botanist could 'only be fully seen in his letters to his most intimate friends'. See Fisher, op. cit. (16), p. vii. There is some suggestion that Harvey intended to revise and publish his letters upon his return as a record of his travels. See Fisher, op. cit. (16), p. 244.
} 
and the same time also distinguishes him as an interesting example and offers a contrast to government-sponsored or commercial collectors. According to Joseph Hooker, Harvey 'calls himself an Amateur only, - lays no claim to be philosophical or scientific'. Although this self-deprecating description glosses over the fact that Harvey was a professor of botany (first to the Royal Dublin Society and subsequently also at Trinity College Dublin), it gives us a sense of the interstitial position he occupied in the world of nineteenth-century natural-history collecting. ${ }^{18}$

As a cultural history of collecting practices, the discussion that follows aims to revise our understanding in several distinct ways. First, by illustrating the difficulties encountered by those collecting (and transporting) specimens, it underlines the contingent nature of such activities. Through the example of Harvey's experiences, this article demonstrates that, far from being a catalogue of continuous success, the story of collecting in the far-flung reaches of Britain's nineteenth-century empire was often littered with failure and disappointment. Second, scouring the letters and correspondence of individual travellers, collectors and naturalists - the kinds of records kept by William Harvey - yields insights into the vast array of individuals involved in such activities. In doing so, the article demonstrates the interactions, encounters and cultural exchanges that were precipitated by even the most basic collecting activity. Scientific networks and scholarly connections were undoubtedly global in their scope and ambition but, as Sarah Easterby-Smith points out, knowledge was often local and depended on individuals who have frequently been omitted from the grand historical narratives of science. ${ }^{19}$

The collecting of algae and other plants on this expedition was shaped by the material culture, embodied knowledge and physical constraints encountered by Harvey along the way. ${ }^{20}$ Collecting activities were facilitated by the connections forged by new technologies and Britain's expanding global empire. But they also depended on specific contexts and relied on local agents, actors and experts, as well as on the physical and technical facilities (and limitations) of those doing the collecting. Harvey's example sheds light on the real, 'lived' experiences of individual collectors, the difficulties and challenges they encountered in amassing their collections, and the networks of people on which they relied.

\section{Collecting practices and the practicalities of travel}

Although Harvey's expedition to Australia occurred at a time when transport and technological developments made it easier to travel, he was still curtailed by the twin perils: 'the slowness and ... the expense of locomotion'.21 And the practicalities and logistics associated with travel, and especially his extensive and specialist luggage, were never far from Harvey's mind either. ${ }^{22}$ We get a sense of the 'formidable array of the requisites for drying seaweeds' in Harvey's Memoir, which were said to consist of, among other things, 'a quantity of coarse towels and blotting-paper, together with boards for pressing,

\footnotetext{
${ }^{18}$ Endersby, op. cit. (3), p. 22.

${ }^{19}$ Easterby-Smith, op. cit. (9), p. 217.

${ }^{20}$ Seaweed had economic and practical applications. It had been employed as fertilizer or fodder for hundreds of years before the discovery, at the end of the seventeenth century, that it could also be used to produce soda ash, an essential component in the manufacture of glass and soap. See J.M. Neeson, 'Coastal commons: custom and the use of seaweed in the British Isles, c.1700-1900', in S. Cavaciocchi (ed.), Ricchezza del Mare, Ricchezza dal Mare, Prato: Istituto Datini, 2006, pp. 345-52. As part of the US North Pacific Exploring Expedition (1853-6), William Stimpson endured the taunts and jeers of his naval companions in consequence of the excitement and enthusiasm' he exhibited 'when a lot of [sea]weed is picked up'. See Ronald Scott Vasile, William Stimpson and the Golden Age of American Natural History, DeKalb: Northern Illinois University Press, 2018, p. 26.

${ }^{21}$ WHH to HHT, 16 May 1854, TCD, MS 3640/16.

${ }^{22}$ For further examples of the kind of equipment taken by others embarking on such collecting trips see Endersby, op. cit. (3), pp. 59-60.
} 
which were furnished with leather straps and buckles'. ${ }^{23}$ Even before he departed, in a letter to Jane Gray, wife of Asa, he lamented,

The bulk and weight of my luggage is so frightful that I am fain to send some by long sea to me at Swan River - and perhaps to go and feed the fishes, on the way out! I must however run the risk. It appears that I must take out paper for drying as well as for laying out specimens upon. ${ }^{24}$

As he anticipated his arrival at Port Said, Harvey fretted about his baggage, worrying that 'rough handling may break the fastenings and scatter the contents to the winds' ${ }^{25}$ In Ceylon, his collections were 'bulky' and 'too weighty to travel fast with'. ${ }^{26}$ He complained to his sister of his 'weary iron boxes' which were his 'greatest plague'. ${ }^{27}$ There was further evidence of this in Australia, as Harvey travelled from Geelong to the entrance to Port Phillip. He paid for 'three places on the post car': 'two of them being charged for my heavy baggage'. Nevertheless, he was thankful for the fact that his fellow travellers did not seem particularly perturbed or 'hampered by my ungainly bundles of paper, iron frames, buckets, bowls, and dishes and baskets! ${ }^{28}$

Harvey's fears about the fragility of his equipment were well placed. His first journey in Ceylon, from Trincomalee at the coast to the gardens at Peradeniya, led to the breaking of the 'Kew Register Thermometer', even 'though it was packed in the middle of my portmanteau'. His sense of frustration is palpable in a letter to Hooker: 'Why do they not put up their thermometers in better cases at the Kew observatory. The metal tube bends (I suppose) in very hot weather and ... this was the cause of breakage of glass. ${ }^{29}$ Harvey was not the only naturalist concerned about packing material, and anything that came to hand was liable to be used by the collector hoping to send material on a long sea voyage. Thomas Maclear, for example, 'amassed a large batch' of the 'South African Newspaper' published at the Cape, to be used 'as partition paper in a box of bulbs' being sent to Britain. ${ }^{30}$

Access to appropriate instruments at the right time was another concern. This is particularly relevant in considering collecting - or opportunities for collecting - on board ship. Although some ships became 'floating laboratories', facilitating the gathering and production of knowledge, many collecting activities were just as likely to be disrupted by the vessel's limitations and constraints. ${ }^{31}$ On his outbound voyage, for instance, William Harvey had to pass up the chance to examine strange 'floating masses of green

\footnotetext{
${ }^{23}$ Fisher, op. cit. (16), p. 37. 'Blotting paper' was one of a variety of different types of paper routinely packed by travelling collectors. It was especially useful in the preparation and preservation of marine plants. See Endersby, op. cit. (3), p. 341 n. 45. The prefatory 'advertisement' in the first volume of Harvey's Phycologia Australica included details of the equipment required by budding seaweed collectors, including baskets, 'flat dishes' and 'wide-mouthed (pickle) bottles', as well as a variety of drying papers. See William Henry Harvey, Phycologia Australica; Or, A History of Australian Seaweeds, 5 vols., London: L. Reeve \& Co., 1858-63, vol. 1, pp. viii-ix.

${ }^{24}$ WHH to Jane Gray, 18 July 1853, in Sophie C. Ducker (ed.), The Contented Botanist: Letters of W.H. Harvey about Australia and the Pacific, Carlton: Melbourne University Press, 1988, p. 57.

${ }^{25}$ WHH to HTT, 15 August 1853, TCD, MS 3640/2.

${ }^{26}$ WHH to William Hooker, 20 November 1853, in Ducker, op. cit. (24), p. 69.

${ }^{27}$ WHH to HHT, 2 December 1853 , TCD, MS 3640/7.

${ }^{28}$ WHH to HHT, 30 November 1854, in Ducker, op. cit. (24), p. 166.

${ }^{29}$ WHH to William Hooker, 9 April 1856, in Ducker, op. cit. (24), p. 277.

${ }^{30}$ Thomas Maclear to John Lee, 12 June 1835, Buckinghamshire Archives, Aylesbury, Papers of Dr John Lee (hereafter BA), D-LE/H/8/13.

${ }^{31}$ On the idea of 'floating laboratories' see Richard Sorrenson, 'The ship as a scientific instrument in the eighteenth century', Osiris (1996) 11, pp. 221-36. See also Claire Warrior and John McAleer, 'Objects of exploration:
} 
scum which filled the sea' in the Malacca Straits simply because his 'microscope was stowed away in the hold'.$^{32}$ There were no boats for hire in Ceylon, only 'rickety canoes, from which you cannot dredge'. ${ }^{33}$ At Peradeniya, the 'chocolate trees [were] laden with fruit', which Harvey intended to preserve 'if I can find large enough jars' ${ }^{34}$ Elsewhere on the island, 'specimens of a curious parasite' piqued Harvey's interest, but he worried about whether he would be able to 'get it safely home' due to a lack of equipment. ${ }^{35}$ In Australia, the supplies of 'Dr Bromfield's red blotting paper' given to him by William Hooker proved to be 'very useless', 'always rotting and tearing', and blowing away 'when put to dry in the sun'. 36

As he moved across the globe, Harvey had to procure smaller items to facilitate his work, such as 'buckets, bowls and plates for algae work'. This was 'an expence to be incurred wherever I pitch my tent', he told his niece, because 'the articles are not worth removing,. ${ }^{37}$ Notwithstanding his willingness to pay for such items, supply was an issue in the more remote corners of the nineteenth-century British Empire:

I have searched every shop for a common dish, earthenware dish and have failed! I could get nothing less than a dinner service and so have to do with two small plates which luckily I brought with me. I shall try to borrow a dish today. ${ }^{38}$

And when he reached South America, on his homeward journey, Harvey found himself 'very badly off for light paper, suitable for mule travelling'. The paper that he had been using was perfectly fine for algae but 'not so good for land plants'. Paper of the kind that he needed now was both expensive and difficult to procure, forcing Harvey to rely on his friend and professional contact, William Hooker at Kew, to send 'four reams by Mail Steamer'. ${ }^{39}$

\section{'Minor troubles, infections and hindrances': challenges in natural-history collecting}

The practical challenges and difficulties involved in the transportation of natural-history specimens across large distances became very familiar to Harvey and his contemporaries. ${ }^{40}$ But these challenges were not new. ${ }^{41}$ And they were particularly acute in the case of living plants. Seeds and living plants on board ship were, as E. Charles Nelson has pointed out, almost permanently at risk from humidity, shortages of water, and extremes of temperature beyond those of their natural habitats. 'Plants on board a ship', as Sir Joseph Banks put it, were 'like cucumbers in February': they required constant

expanding the horizons of maritime history', in Charles W.J. Withers and Fraser MacDonald (eds.), Geography, Technology and Instruments of Exploration, Farnham: Ashgate, 2015, pp. 97-118.

${ }^{32}$ WHH to HHT, 'the feast of St Thomas' [21 December], 1853, TCD, MS 3640/8. Harvey offers no details about the kind of microscope that he had packed, although it was likely to have been a relatively large and expensive compound microscope of the kind required for analysing the cryptogams studied by Harvey. See Endersby, op. cit. (3), pp. 72-4.

${ }^{33}$ WHH to HHT, 14 September 1853, in Fisher, op. cit. (16), p. 251.

${ }^{34}$ WHH to HHT, 28 September 1853 , TCD, MS 3640/3.

${ }^{35}$ WHH to HHT, 28 September 1853 , TCD, MS 3640/3.

${ }^{36}$ WHH to William Hooker, 9 April 1856, in Ducker, op. cit. (24), p. 277. For more on the kinds of paper used by travelling botanists see Endersby, op. cit. (3), p. 67.

${ }^{37}$ WHH to his niece, Mary Christy Harvey (hereafter MCH), 21 April 1854, TCD, MS 3640/15.

${ }^{38}$ WHH to MCH, 21 April 1854, TCD, MS 3640/15.

${ }^{39}$ WHH to William Hooker, 9 April 1856, in Ducker, op. cit. (24), p. 277.

${ }^{40}$ WHH to RH, 20 November 1853, TCD, MS 3640/6.

${ }^{41}$ In a letter published in 1791, the French gardener Hippolyte Nectoux emphasized that transporting plants by sea required 'study [and] vigilance'. See Easterby-Smith, op. cit. (9), pp. 233-8. See also Christopher M. Parsons and Kathleen S. Murphy, 'Ecosystems under sail: specimen transport in the eighteenth-century French and British Atlantics', Early American Studies: An Interdisciplinary Journal (2012) 10(3), pp. 503-29. 
attention. ${ }^{42}$ They were susceptible to salt air and salt water. And they also were vulnerable to the antipathy of ships' crews who were often treated with less indulgence than their living cargoes-something the mutiny on William Bligh's Bounty underlined. ${ }^{43}$ John Woodward's instructions for 'Collecting, Preserving, and Sending over Natural Things' from overseas, published in 1696, highlighted the myriad ways in which, as Arthur MacGregor puts it, 'the best-ordered fieldwork could be subverted during the process of transportation'. ${ }^{44}$ Sailors unsympathetic to the cause of science were only part of the problem, which persisted up to and included the passage of collections through Customs and Excise; 'especially for the natural things, that are thus sent over, great caution ought to be used that the boxes wherein they are, be not turned topsy-turvy, or much tumbled and shaken in carrying to and from the ship'. ${ }^{45}$ By the nineteenth century, many collectors like William Harvey were just as interested in dead or dried specimens for the purposes of taxonomy. But challenges persisted. In Harvey's case, his problems ranged from those associated with gathering plants and preserving specimens in situ to their storage and the expense and difficulties of their transportation.

During his six-year sojourn as a government official in the Cape Colony in the mid-1830s, Harvey lamented that it is a great plague to gather seeds and bulbs in a wild state, more so than can be imagined'. ${ }^{46}$ Nearly two decades later, Harvey reflected that, although his time at Ceylon was less 'successful botanically' than he had anticipated, it had made him 'greatly au fait at the work before me, and enabled me to supply myself with sundry necessaries for collecting, which I had neglected to take; but chiefly, it has hardened me gradually to roughing it' ${ }^{47}$ If collecting in the field was tough, ordering and arranging his finds were just as trying. Limited living space meant that, during his time in Cape Town, Harvey's bedroom served as 'study, herbarium, and shell room, and you know a naturalist in preparing his goods breeds odours little to be desired in a sleeping apartment'. ${ }^{48}$ Fifteen years later, Harvey was still suffering from limited living quarters. In his room at the Brighton Hotel in Port Phillip, Harvey secured 'a garret room up in the roof, lighted by a skylight of one pane of glass about twice the size of an ordinary "porthole"'. Space was at a premium, forcing Harvey to do all of his sorting and sifting 'at a little table, hiding the papers and parcels under the bed'. ${ }^{49}$

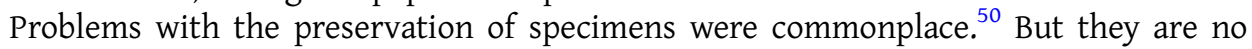
less instructive for all that, underlining the many trials and multiple errors endured by

\footnotetext{
${ }^{42}$ Sir Joseph Banks, 'Instructions to the gardeners on the Guardian' [July 1789], in Alan Frost, Sir Joseph Banks and the Transfer of Plants to and from the South Pacific, 1786-1798, Melbourne: Colony Press, 1993, p. 26.

${ }^{43}$ E. Charles Nelson, 'From tubs to flying boats: episodes in transporting living plants', in MacGregor, op. cit. (7), pp. 578-606.

${ }^{44}$ Arthur MacGregor, 'Introduction', in MacGregor, op. cit. (7), pp. 1-39, 22.

${ }^{45}$ John Woodward, Brief Instructions for Making Observations in All Parts of the World as also, for collecting, preserving, and sending over Natural Things, London: Richard Wilkin, 1696, p. 15. For more on the hardships and obstacles including climate, weather, disease and human impediments - facing those moving natural-history specimens around the Atlantic world in particular, see Londa Schiebinger, Plants and Empire: Colonial Bioprospecting in the Atlantic World, Cambridge, MA: Harvard University Press, 2004, pp. 69-72.

${ }^{46}$ WHH to Mrs L[eadbeate]r, 16 January 1836, in Fisher, op. cit. (16), p. 74. See E. Charles Nelson, 'William Henry Harvey as colonial treasurer at the Cape of Good Hope: a case of depression and bowdlerized history', Archives of Natural History (1992) 19(2), pp. 171-180, 176. For more on Harvey's botanical work at the Cape see Mary Gunn and L.E. Codd, Botanical Exploration of Southern Africa, Cape Town: A.A. Balkema, 1981, pp. 179-181.

${ }^{47}$ WHH to Nathaniel Bagshaw Ward (hereafter NBW), 20 November 1853, in Fisher, op. cit. (16), p. 261.

${ }^{48}$ WHH to Mrs L[eadbeate]r, 25 January 1837, in Fisher, op. cit. (16), p. 83.

${ }^{49}$ Fisher, op. cit. (16), p. 279.

${ }^{50}$ See Robert McCracken Peck, 'Preserving nature for study and display', in S.A. Prince (ed.), Stuffing Birds, Pressing Plants, Shaping Knowledge: Natural History in North America, 1730-1860, Philadelphia: American Philosophical Society, 2003, pp. 11-26; Peck, 'Brief histories of preservation techniques', in Prince, op. cit., pp. 27-54.
} 
collectors and their correspondents. Thomas Maclear was Astronomer Royal at the Cape of Good Hope. Trained as a physician before taking up his telescope, Maclear was less interested in botany or maritime collecting than was Harvey (although, like many others, he collected seaweed samples). Nevertheless, he still needed ships to transport to Britain specimens collected in South Africa-including fragments of an asteroid that he came across - and his efforts were subject to many of the same challenges as Harvey's. For instance, among the 'trifling specimens' that Maclear had prepared to send to John Lee, an antiquary and founding member of the Astronomical Society, was an 'enormous frog'. But the creature became 'putrescent and dealt mischief right and left', thereby curtailing the sending of the entire consignment. ${ }^{51}$ The preservation and transportation of birds from their exotic origins to British collections were also contentious matters. Maclear was confused about the best way to proceed, "whether to have them put up [i.e. stuffed] here [in South Africa], or to leave it to be done in England'. His solution was to rely on evidence and empirical data-trial and error, in other words - to see how they fared on the voyage northwards across the expanse of the Atlantic Ocean. Maclear told Lee that he had sent a collection of birds to Sir George Magrath, a naval surgeon and friend of the Maclear family based in Portsmouth, some of which had already been preserved at the Cape. Magrath was yet to pronounce on their condition. But Maclear assured Lee that 'if they arrive in good preservation I propose to follow the same plan with you', before proceeding to describe the method in some detail: 'The birds carefully skinned and dried are packed up with sprinklings of tobacco leaf. The whole inclosed in a tin case soldered - and then in a deal box. ${ }^{52}$

The natural world presented difficulties and inconveniences for Harvey. He admitted that his botanical expedition into the interior of Ceylon was hampered by 'land leeches'. It was impossible to 'stand for a moment', he announced, 'without seeing a troop of them coming towards you from every side': 'They come and are soon up your legs if you go without gaiters and [they are] always hungry. ${ }^{, 53}$ The incessant rain encountered later in the excursion presented the travellers with difficulties getting their baggage across the surging river. ${ }^{54}$ Even back in his room at the botanic garden, problems arose:

On wet evenings white ants are very troublesome ... In they come in troops, fly round and round, flap in your face, settle in your hair, on the dinner table, dishes, anywhere and commence desperate efforts to get rid of their wings. They twitch them backwards and forwards till they fall off and the insect crawls away to commence its mischievous mining life. They eat almost anything and are the great pest of the land. ${ }^{55}$

Harvey professed himself glad to have visited Ceylon, even though it did not prove particularly profitable in terms of collecting. It had, however, 'opened my eyes to the troubles of collecting in rude countries and I am much better prepared for roughing it than I was'. ${ }^{56}$

Harvey's letters are replete with details of everyday activities and mundane concerns, which highlight some of the prosaic and practical considerations that impinged on an

\footnotetext{
${ }^{51}$ Thomas Maclear to John Lee, 17 November 1836, BA, D-LE/H/8/18.

52 Thomas Maclear to John Lee, 12 June 1835, BA, D-LE/H/8/13.

${ }^{53}$ WHH to HHT, 28 September 1853 , TCD, MS 3640/3.

${ }^{54}$ WHH to HHT, 24 October 1853 , TCD, MS 3640/4.

${ }^{55}$ WHH to RH, 20 November 1853, TCD, MS 3640/6. Robert Plant in Natal was another who found termites troublesome: they 'devoured' all of the natural history books that he had taken to Natal with him. See Donal P. McCracken, 'Robert Plant (1818-1858): a Victorian plant hunter in Natal, Zululand, Mauritius and the Seychelles', South African Journal of Science (2011) 107(3-4), pp. 1-7, 2.

${ }^{56}$ WHH to William Hooker, 20 November 1853, in Ducker, op. cit. (24), p. 68.
} 
expedition's successes. For example, one of the key advantages of the 'little seaside inn' at Weligama, where Harvey lodged during his stay on the south coast of Ceylon, was the fact that it offered 'excellent accommodation for drying plants', an activity which required significant amounts of space. ${ }^{57}$ Collecting was also dependent on favourable weather conditions. It was 'pretty hot under a vertical sun' in Ceylon with the result that Harvey suffered from 'compulsory idleness' ${ }^{58}$ In his early days in Australia, Harvey's efforts were also hampered 'by reason of wind and storm. I have been out only one day, and then had poor success'. ${ }^{59}$ For a seaweed collector, however, rough seas and strong winds could be a boon. ${ }^{60}$ For this reason, Harvey changed his travel plans and stayed at King George's Sound, in Western Australia, to take advantage of 'a storm which threw up a quantity of weeds and in one day I collected and preserved 700 specimens and several new kinds came in'. ${ }^{61}$ And shore collecting in Van Diemen's Land depended on 'gales of wind which may or may not come'. ${ }^{62}$

Animals presented additional problems. Thomas Maclear was on the brink of collecting a puff adder for his friend and contact, John Lee. But identifying the live animal did not automatically ensure a useable specimen: the 'enormous size and the danger from such a monster compelled me to destroy it', so that 'the methods adopted on the occasion for personal security mutilated it so much that the specimen was spoiled'. ${ }^{63}$ Harvey suffered in like manner. In a shoreside pool in Newcastle, New South Wales, Harvey found a 'great slug' which he promptly killed and took the shell. He regretted it, however, regarding it as 'a murder' and preferring to preserve the creature 'in spirits had he not been too big to go into an ordinary pickle bottle'. ${ }^{64}$ In Van Diemen's Land, Harvey encountered 'some pretty blue centipedes', but 'having no bottle to put them, or nippers to pick them up with, I thought it best to let them alone'. ${ }^{65}$ And during his visit to Tonga, Harvey 'met with a very remarkable star fish of the pentagonal type as large and as thick as a 4lb loaf of bread'. Sadly for Harvey, though, 'this was its dimensions when living but it has very much shrunk in drying and it is now no more than an inch in thickness and quite flat', rendering it practically useless as a scientific specimen: 'I have preserved two specimens by simply drying (they stank abominably for 3 or 4 weeks) and three more, I cut open and skinned and have preserved only the skin and skeleton. ${ }^{66}$ Living plants could also be problematic. Elsewhere in the South Pacific, Harvey collected seeds and specimens of 'a very remarkable fern', which he took 'in a Ward's case to Sydney', hoping they would survive long enough to reach Glasnevin. But he had his doubts: 'I do not like the look of them at present, poor things. ${ }^{167}$

\footnotetext{
${ }^{57}$ WHH to RH, 20 November 1853, TCD, MS 3640/6.

${ }^{58}$ Fisher, op. cit. (16), p. 251.

${ }^{59}$ Fisher, op. cit. (16), p. 266.

${ }^{60}$ For example, in his 'Short directions for collecting \& preserving Seaweeds', written for Charles Wilford in the mid-1850s, William Hooker remarked that a great many species were washed ashore after a storm. See Endersby, op. cit. (3), p. 71.

${ }^{61}$ WHH to HHT, 22 February 1854 , TCD, MS 3640/11.

${ }^{62}$ WHH to HHT, 15 January 1855 , TCD, MS $3640 / 20$.

${ }^{63}$ Thomas Maclear to John Lee, 6 September 1837, BA, D-LE/H/8/20.

${ }^{64}$ WHH to HHT, 15 May 1855, TCD, MS 3640/24. On the importance of bottles, vessels and receptacles see Anne Secord, 'Containers and collections', in Helen A. Curry, Nicholas Jardine, James A. Secord and Emma C. Spary (eds.), Worlds of Natural History, Cambridge: Cambridge University Press, 2018, pp. 289-303.

${ }^{65}$ WHH to HHT, 9 February 1855, in Ducker, op. cit. (24), p. 184.

${ }^{66}$ WHH to HHT, 12 December 1855, TCD, MS 3640/29. For more on the context of European collecting in the Pacific in the period see Robert Huxley, 'More than one way to skin a wombat: the how and why of collecting in the South Seas', in MacGregor, op. cit. (7), pp. 470-99.

${ }^{67}$ WHH to MCH, 13 December 1856 [sic; recte 1855], TCD, MS 3640/30.
} 
Quite apart from the physical difficulties involved, the sheer expense of transporting specimens across the world's oceans was a major stumbling block for many collectors. Unlike government-sponsored expeditions, Harvey, Maclear and others were generally collecting for themselves or their contacts. ${ }^{68}$ Large trading companies could afford to sponsor the transportation of specimens. In the 1860s, for example, the Hudson's Bay Company contributed greatly to the collections of the Smithsonian Institution in Washington, DC by waiving freight charges. ${ }^{69}$ However, the individual collector, without the backing of an official or government-sponsored expedition, was rarely so lucky. Nearly twenty years before he embarked for Australia, Harvey realized the pecuniary constraints on his activities, acknowledging that he was "not rich enough to go touring round the world, spending here and there'. If he was going to travel, 'it must be in a way not to return poorer, if I do not return richer' ${ }^{70}$ During his time in South Africa, Harvey complained about the cost of hiring a horse to help with his botanical endeavours: 'fifteen shillings is too much to pay every time I want to pick up some weeds' ${ }^{71}$ Even in transporting plants across the Irish Sea, Harvey had to consider the cost. As he prepared to leave for Australia, Harvey arranged for some specimens to be sent from Kew to a friend in Dublin: 'Let it be marked luggage train', he instructed William Hooker, 'as it will only make a delay of 24 hours and will make a wonderful difference in cost of carriage'. ${ }^{72}$

Like many of his contemporaries, and in spite of his position as professor of botany, Harvey was an independent collector who played an active role in the nineteenth-century natural-history specimen market, in order - partially at least - to fund his scientific pursuits. ${ }^{73}$ Before he embarked for the southern hemisphere, Harvey outlined his plan to Asa Gray, professor of botany at Harvard and an important professional contact:

I mean to collect algae largely in duplicate and to sell fasciculi of them on my return, so as to pay a part of the expences - and I hope that shells may pay another part - so that if I live to come home again I shall nearly pay my way and have besides a noble collection of marine productions. ${ }^{74}$

${ }^{68}$ Robert Kohler notes that many museum curators collected on unpaid work vacations. See Kohler, op. cit. (4), p. 91. Harvey acknowledged the contributions of the Royal Dublin Society and Trinity College Dublin to his travels, although he also made clear that he relied on selling duplicates to pay 'the expenses of the journey'. Harvey, op. cit. (23), vol. 1, p. v.

69 Ted Binnema, Enlightened Zeal: The Hudson's Bay Company and Scientific Networks, 1670-1870, Toronto: University of Toronto Press, 2014, p. 266.

${ }^{70}$ WHH to Hooker, 12 November 1834, in Fisher, op. cit. (16), p. 43.

${ }^{71}$ Fisher, op. cit. (16), p. 128.

${ }^{72}$ WHH to William Hooker, 15 February 1853, in Ducker, op. cit. (24), p. 38.

${ }^{73}$ Naraisara Murray, 'From bird of paradise to Drosophila: the changing roles of scientific specimens to 1920', in Kathleen Kete (ed.), A Cultural History of Animals: The Age of Empire, 1800-1920, Oxford: Berg, 2007, pp. 113-34, 122. For further discussion of the blurred lines between professional practitioners of science and their need to earn a living see Patience A. Schell, 'Natural history values and meanings in nineteenth-century Chile', Notes and Records (2019) 73, pp. 101-24, 119-20. See also David Elliston Allen, 'The early professionals in British natural history', in Alwyne Wheeler and James Henry Price (eds.), From Linnaeus to Darwin: Commentaries on the History of Biology and Geology, London: Society for the History of Natural History, 1985, pp. 1-12; Anne Coote, Alison Hayes, Jude Philp and Simon Ville, 'When commerce, science and leisure collaborated: the nineteenth-century global trade boom in natural history collections', Journal of Global History (2017) 12(3), pp. 319-39; Ruth Barton, “"Men of science”: language, identity, and professionalization in the mid-Victorian scientific community', History of Science (2003) 41, pp. 73-119.

${ }^{74}$ WHH to Asa Gray, 24 February 1853, in Ducker, op. cit. (24), p. 40. The intention to sell fascicules of specimens to aid the work of classification was typical among those in engaged in cryptogamic botany. Harvey knew that he could recoup some money by selling seaweed specimens because, as with shells, such specimens were desirable for both scientific and aesthetic reasons. I am indebted to the anonymous reader for this point. 
Here he was relying on the fascination evinced by European amateurs of natural history, as well as professionals and museum curators, for Antipodean flora and fauna. ${ }^{75}$ Writing from Weligama, Harvey updated his brother on the commercial prospects of the voyage. He anticipated amassing ' $£ 80$ to $£ 100$ of algae', for which he envisaged 'a ready sale as some of the new species among them are exceedingly curious and beautiful and will carry the sale of the rest'. ${ }^{76}$ The following month, Harvey confirmed that eighteen days spent at this small fishing village on the south coast of the island had yielded nearly one hundred different species of seaweed, almost five thousand specimens in total: 'The sale of the duplicates from this collection will, should they arrive safely, in Ireland, nearly cover my expences in Ceylon (£80). ${ }^{, 77}$

As he embarked on his Australian collecting efforts, Harvey lamented his inability to send his brother-in-law a 'box of roots' from King George's Sound in Western Australia, 'but expence forbids'. ${ }^{78}$ In another case, however, he arrived at a creative solution, addressing one box of seaweeds from Ceylon 'to R[obert] Ball so that TCD may have the pleasure of paying freight for the same'. ${ }^{79}$ Arranging payments at such removes also proved complicated and involved many individuals in several settlements. ${ }^{80}$ All in all, collecting was 'slow work', he told his sister, but he could not afford an assistant although this would have permitted him to do a great deal more. ${ }^{81}$ And when he got to South America, on his homeward-bound journey, his collecting activities there were also hampered by the expense. He professed himself willing to collect cacti for Kew but only on the condition that he would be 'allowed to sell the duplicates as remuneration for my trouble'. ${ }^{82}$

This aspect of the practicalities of collecting and transportation also impinged on the activities of Thomas Maclear. He apologized to John Lee for not sending the trumpet sea weed' immediately. The specimen would have filled an entire box, and Maclear 'did not think it worth the expence'. But he assured Lee that a specimen of the plant would eventually get to Buckinghamshire, observing, 'when you open the box you will fancy I have sent you the leather pipe of a fire engine'. ${ }^{83}$ Eventually, Maclear got wise to the problems caused by expensive freight and customs charges. He sent Sir George Magrath 'a carpet for his museum composed of some 50 springbok skins'. There was some doubt, however, whether it would pass as a specimen of natural history or be charged as a trade item: 'I applied at the Custom House in Cape Town to know if they would be charged with a duty as hides. They could not tell me but requested me to write "natural curiosities" on the box. I did so. ${ }^{, 84}$ In this case, and assuming his labelling was successful, Maclear was assisted by the repeal of prohibitively expensive customs duties on natural-history specimens in $1824 .^{85}$

\footnotetext{
${ }^{75}$ See Tom Griffiths, Hunters and Collectors: The Antiquarian Imagination in Australia, Melbourne: Cambridge University Press, 1996, pp. 18-21.

${ }^{76}$ WHH to RH, 20 November 1853, TCD, MS 3640/6, original emphasis.

${ }^{77}$ WHH to HHT, 2 December 1853, TCD, MS 3640/7. As a comparison, Robert Plant's commercial collecting endeavours in Natal could yield thirty-five pounds per consignment shipped to Samuel Stevens, a London dealer in 'natural curiosities'. See McCracken, op. cit. (55), p. 2.

${ }^{78}$ WHH to Thomas Harvey Todhunter, 28 January 1854, TCD, MS 3640/10.

${ }^{79}$ WHH to HHT, 2 December 1853, TCD, MS 3640/7. Robert Ball was the director of Trinity College Museum and father of the astronomer Robert Stawell Ball. Charles Darwin did something similar. Even though he was a private passenger on HMS Beagle, Darwin sent his materials and specimens back to Britain at the expense of the Admiralty. See Camerini, op. cit. (12), p. 363.

${ }^{80}$ See, for example, WHH to William A. Sanford, 9 January 1854, in Ducker, op. cit. (24), p. 72.

${ }^{81}$ WHH to HHT, 16 May 1854, TCD, MS 3640/16.

${ }^{82}$ WHH to William Hooker, 9 April 1856, in Ducker, op. cit. (24), pp. 275-6.

${ }^{83}$ Thomas Maclear to John Lee, 12 June 1835, BA, D-LE/H/8/13.

${ }^{84}$ Thomas Maclear to John Lee, 12 June 1835, BA, D-LE/H/8/13.

${ }^{85}$ See Anne Laurine Larsen, 'Not since Noah: the English scientific zoologists and the craft of collecting, 18001840', unpublished PhD thesis, Princeton University, 1993, p. 257.
} 
Negotiating with customs officials sometimes required ingenuity or involved other difficulties. In 1801, James Grant, commander of the Lady Nelson during its survey of Australia in 1800 , sent 'new plants especially of the fern tribe' to Sir Joseph Banks via Captain Bunker 'between the leaves' of a West India Pilot, a book of navigation instructions, which was consequently less likely to be examined for contraband imports in the hands of a mariner. ${ }^{86}$ And when Joseph Beete Jukes arrived in London in 1846 following his survey work in HMS Fly, the jars full of specimens (or more accurately the alcohol used to preserve them) aroused the suspicions of a customs officer who promptly emptied the jars, almost destroying the specimens before they reached Edward Gray at the British Museum. $^{87}$

On other occasions, the difficulties could be more dramatic and potentially catastrophic. The dangers of mislaying specimens or, in the most extreme cases, losing material as a result of shipwreck or fire were never far from the minds of naturalists. As we have seen, William Harvey fretted that the 'bulk and weight' of his luggage for Australia meant that he had to send equipment and instruments ahead with the attendant risk that they would 'go and feed the fishes on the way out'. ${ }^{88}$ Presumably he harboured similar fears for homeward-bound specimens. In some instances, Harvey's letters take us beyond his own personal experiences and reflect the difficulties faced by his fellow labourers in the field. When he arrived in Australia, Harvey informed William Hooker that one of their mutual acquaintances, Baron Ferdinand von Mueller, recently appointed government botanist to the colony of Victoria, was 'very anxious about some parcels of plants and MS descriptions sent to you by Governor Latrobe, to whom they were entrusted so long back as October 1853, and of which he has never since heard ${ }^{89}$ Clearly and understandably, Mueller feared the worst: the complete loss of the consignment. In this instance, Harvey could only provide pastoral support, reassuring Mueller that Hooker would write to him as soon as he received the material.

Practical dangers and difficulties of this sort scuppered the collecting activities of others. Alfred Russel Wallace's finances were only saved from disaster when the ship carrying his specimens from South America burnt and sank because his agent, the dealer Samuel Stevens, had insured them for $£ 200 .{ }^{90}$ But his collections were dealt a major setback and much irreplaceable material was lost. Robert Plant dispatched forty-five healthy orchid plants from Mauritius to the same dealer, packed in a barrel, which was subsequently lost by the shipping company. ${ }^{91}$ Clarke Abel, who accompanied Lord Amherst's ill-fated embassy to China in 1816, was another whose collecting efforts suffered from the vicissitudes of both nature and man. In Abel's case, expense was not a problem - this was a government-funded mission. But the dangers associated with natural disasters and human incompetence were ever-present. Abel recorded in his published account that 'shipwreck almost annihilated the materials which would have afforded

\footnotetext{
${ }^{86}$ Quoted in Daniel Simpson, 'Ethnographic collecting and the despotism of Joseph Banks', Journal for Maritime Research (2019) 21(1-2), pp. 77-95, 87.

${ }^{87}$ See Daniel Simpson, 'Agency, encounter and ethnographic collecting: the Royal Navy in Australia, c.17721855', unpublished PhD dissertation, Royal Holloway, University of London, 2018, p. 323.

${ }^{88}$ WHH to Jane Gray, 18 July 1853.

${ }^{89}$ WHH to William Hooker, 5 September 1854, in Ducker, op. cit. (24), p. 138.

90 A.M. Lucas and P.J. Lucas, 'Natural history “collectors": exploring the ambiguities', Archives of Natural History (2014) 41(1), pp. 63-74, 65. See Peter Raby, Alfred Russel Wallace: A Life, London: Chatto \& Windus, 2001, p. 3. The potential consequences of such disasters were particularly catastrophic for someone in Wallace's position. In contrast to Harvey, who aimed merely to cover the costs of his travel, Wallace relied on the proceedings of selling specimens to earn a living. My thanks again to the anonymous reader for alerting me to this point.

${ }^{91}$ McCracken, op. cit. (55), p. 3.
} 
extensive scientific communication respecting China'. ${ }^{92}$ Worse was to follow. Abel subsequently learned that the cases containing three hundred packages of seeds from China had been 'emptied of their contents by one of the seamen, to make room for some of the linen of one of the gentlemen of the embassy'. ${ }^{93}$ In the same vein, on his way back from Australia, William Harvey met a Mr Cood in the vicinity of Valparaiso who wondered if his specimens of 'melon cactus' had not suffered the same fate. Cood had sent a 'large crate of them some long time ago, by a naval steamer', addressed to William Hooker at Kew. But Hooker never acknowledged the consignment, leaving Harvey to speculate that 'a snob of a first lieutenant pitched them overboard as a piece of lumber - I should not wonder - for when so far removed from home as the Pacific is, some very queer things happen on shipboard'. ${ }^{94}$

Natural-history collecting was a popular activity, and its popularity reached beyond practitioners of science. But it was tough, even for people like William Harvey and Thomas Maclear. It demanded perseverance, resourcefulness and resilience. And it also required help.

\section{Natural-history networks}

William Harvey was good at making and retaining friends. ${ }^{95}$ In the context of a naturalhistory collecting expedition, personal amiability and natural disposition were aided by the social contacts and cultural capital that Harvey could draw on in the course of the voyage. Many of his personal encounters were facilitated by shared scientific interests or mutual acquaintances, such as William Hooker at Kew. In Ceylon, Harvey stayed with George Thwaites, the superintendent of the botanic gardens at Peradeniya, who promised to continue some of the former's collecting activities and send the results to Dublin. ${ }^{96}$ At Singapore, Harvey spent time with Thomas Oxley, an alumnus of TCD and friend of William Hooker, while William Ayshford Sanford, the colonial secretary in Western Australia, also provided assistance on the basis of a mutual friendship with Hooker. ${ }^{97}$ Harvey's boxes and equipment were 'shipped to his care from London to await my arrival here'. ${ }^{98}$ In Melbourne, Harvey 'made great friends' with Ferdinand von Mueller, 'the Govt Botanist, an excellent fellow and good observer':

He has placed all his algae at my disposal and given me much information besides of a local character and also given me duplicates of his land plants collected among the mountains of the interior where I cannot afford to travel. ${ }^{99}$

\footnotetext{
${ }^{92}$ Clarke Abel, Narrative of a Journey in the Interior of China, and of a Voyage to and from that Country, in the Years 1816 and 1817, London: Longman, Hurst, Rees, Orme, and Brown, 1818, p. vi.

${ }^{93}$ Abel, op. cit. (92), p. vii n.

${ }^{94}$ WHH to William Hooker, 9 April 1856, in Ducker, op. cit. (24), p. 277.

${ }^{95}$ John Parnell, “'William cares for nothing but weeds”: W.H. Harvey (1811-1866) and systematic botany in Trinity College Dublin', in David Scott (ed.), Treasures of the Mind: A Trinity College Dublin Quatercentenary Exhibition, London: Sotheby's, 1992, pp. 79-88, 83.

${ }^{96}$ Ray Desmond, Dictionary of British and Irish Botanists and Horticulturalists, London: Natural History Museum, 1994, p. 685.

97 Thomas Oxley (1805-86) was senior surgeon at the Straits Settlement when Harvey visited. As well as entomology, Oxley had an interest in the economic potential of gutta-percha trees. See Desmond, op. cit. (96), p. 530.

${ }^{98}$ WHH to HHT, 13 April 1854, TCD, MS 3640/14. On the creation of natural-history interest in settler society see Tanja Hammel, Shaping Natural History and Settler Society: Mary Elizabeth Barber and the Nineteenth-Century Cape, London: Palgrave Macmillan, 2020.

${ }^{99}$ WHH to HHT, 14 September 1854 , TCD, MS 3640/18. The practice of specimen exchange was commonplace among nineteenth-century natural historians and museum curators. For further details on this in the Australian context see Gareth Knapman, 'Curiosity or science in the National Museum of Victoria: procurement networks
} 
Harvey speculated on the assistance that he might derive from Charles Latrobe, the first lieutenant governor of Victoria, who was 'fond of Natural History and collects algae himself. ${ }^{100}$ To that end, he was carrying letters of introduction from Latrobe's brother, a clergyman in England, and the Duke of Newcastle. In New Zealand, Harvey was warmly welcomed by the colonial secretary, Andrew Sinclair, who had extensive botanical interests, having collected avidly during his time as a naval surgeon on the South Africa station and aboard HMS Sulphur on its survey of the South American coast in the 1830s. ${ }^{101}$ Harvey also benefited from the 'fine microscope' belonging to a 'fellow worker', Charles Knight, the first auditor general of the colony. Knight was an excellent draughtsman who agreed to send Harvey 'drawings and specimens of the smaller algae' that he came across. ${ }^{102}$

Harvey's correspondence also underscores the role played by Hannah Todhunter, his sister, in sustaining and cultivating botanical networks across the globe. On several occasions, she passed on the seeds enclosed with Harvey's letters to David Moore, the director of the Royal Dublin Society's botanic garden at Glasnevin. ${ }^{103}$ Hannah's knowledge and expertise were evident in Harvey's surprise at her reaction to his account of Australian tides: 'is it not written in the work of Flinders?' he asked, clearly assuming that his sister was familiar with this explorer's account of his travels. ${ }^{104}$ Harvey also relied on Hannah for news about the fate of his collections in Dublin. He was glad to hear about the safe arrival of some algae, and hoped that

$\mathrm{R}$ [obert] Ball has put into a new glass jar of Goodly the magnificent specimens of Langsdorfia (the fungus looking plant) which were in a large earthen jar. Pray ask after them and let me know as this is a valuable specimen for [the] Herb[arium] which I should be sorry to have lost. ${ }^{105}$

Harvey had long-standing connections with other female botanists and collectors in the British Isles. He knew algologists like Amelia Griffiths and Mary Wyatt, acknowledging his 'obligations to my friend Mrs Griffiths for a most liberal supply of all the interesting plants of her beautiful neighbourhood' in the 1841 edition of his Manual of the British Algae. ${ }^{106}$ It comes as no surprise, therefore, that Harvey cultivated connections with female plant collectors on his travels. ${ }^{107}$ At Matara, in southern Ceylon, he gave Mrs Forbes some specimens of seaweed 'as an inducement to her to collect them'. ${ }^{108}$ And in Australia, Harvey was 'indebted' to the efforts of a Miss Taylor for collecting the seeds of a fragrant brown boronia which he subsequently sent to Moore in

and the purpose of a museum', in Sarah Longair and John McAleer (eds.), Curating Empire: Museums and the British Imperial Experience, Manchester: Manchester University Press, 2012, pp. 82-103.

${ }^{100}$ WHH to RH, 20 November 1853, TCD, MS 3640/6. In some ways, this mirrors the process described by Zoë Laidlaw, in which colonial officials sought to gain professional advantage by developing influential contacts among patrons in Britain with an interest in natural history. See Zoë Laidlaw, Colonial Connections, 1815-45: Patronage, the Information Revolution and Colonial Government, Manchester: Manchester University Press, 2005, pp. 31-5.

${ }^{101}$ Fisher, op. cit. (16), p. 294.

${ }^{102}$ WHH to HHT, 30 June 1855, TCD, MS 3640/26. In 1852 Knight had bemoaned his 'imperfect' microscope, telling his correspondent that he was eagerly anticipating 'the receipt of one of Smith and Becks dissecting Microscope [sic]'. See Endersby, op. cit. (3), p. 75.

${ }^{103}$ WHH to HHT, 24 October 1853, TCD, MS 3640/4. Harvey sent more seeds to Moore, via his sister, from King George's Sound in Australia. See WHH to Thomas Harvey Todhunter, 28 January 1854 TCD, MS 3640/10.

${ }^{104}$ WHH to HHT, 4 March 1855, TCD, MS 3640/22.

${ }^{105}$ WHH to HHT, 9 February 1855, in Ducker, op. cit. (24), p. 182.

${ }^{106}$ William Henry Harvey, A Manual of the British Algae, London: John Van Voorst, 1841, p. lv.

${ }^{107}$ For other examples of female collectors in Australia see Endersby, op. cit. (3), p. 105.

${ }^{108}$ WHH to HHT, 2 December 1853, TCD, MS 3640/7. 
Glasnevin. ${ }^{109}$ Upon his arrival at Van Diemen's Land, he introduced himself to Reverend John Fereday, 'having heard previously that his wife was a collector of seaweeds'. Looking over Susan Fereday's collection uncovered several specimens 'new to me' and Harvey was doubtless grateful to be promised her duplicates. She was acknowledged in Harvey's Phycologia Australica as 'an accomplished and successful collector of algae'. ${ }^{110}$ But the clergyman was just as much an amateur, displaying 'a most enthusiastic fondness for natural history in all shapes and a love for algae in particular'. ${ }^{111}$ In most of these examples, the people enlisted by Harvey were part of his personal or professional networks, or those with whom Harvey shared a vaguely equivalent social status. But in order to be successful, a collecting expedition needed a much wider circle of experts and allies.

\section{Experts, allies and collectors on the spot}

Considering the practicalities and logistics associated with the collecting and transporting of natural-history specimens also broadens our understanding of who contributed to this work. For example, in his study of New England shells published in 1851, William Stimpson cited sixteen men who supplied him with specimens, ranging from physicians and boat captains to wood carvers and fellow naturalists. ${ }^{112}$ The particular complexities and difficulties involved in collecting and classifying cryptogams meant that access to well-prepared specimens, rather than illustrations, was critical. ${ }^{113}$ As a result, finding reliable collectors to prepare specimens with the requisite skill and attention to detail was crucial. Other branches of natural-history collecting were equally dependent on the work of amateur collectors. ${ }^{114}$ Thinking about collecting activities allows us, at least in some cases, to rescue from anonymity what A.M. Lucas and P.J. Lucas call the 'invisible collector', countering a narrative that professional natural historians and ship's surgeons were the only conduits for retrieving, collecting and computing this information. ${ }^{115}$ Henrika Kuklick has demonstrated that the labour performed by naturalists was often divided along class lines. Much of the requisite work to preserve specimens was 'unpleasant and inglorious', perhaps even dangerous: 'And if certain fieldwork tasks were recognised as extraordinarily delicate procedures - such as killing insects without mutilating them - many others were supposed to require so little skill that they could safely be entrusted to virtually anyone. ${ }^{116}$ Part of the skill of the time-limited botanist was the ability to identify which tasks could be entrusted to others and the level of speed, skill and local expertise these tasks required.

Bronwen Douglas has suggested that if maritime connections facilitated the collecting and transmission of information about the wider world (specifically Oceania in Douglas's

\footnotetext{
${ }^{109}$ WHH to HHT, 22 February 1854 , TCD, MS 3640/11.

${ }^{110}$ Harvey, op. cit. (23), vol. 4, dedication.

${ }^{111}$ WHH to HHT, 15 January 1855, TCD, MS 3640/20. For more on the natural-history activities of the clergy in the Australian context see L.A. Gilbert, 'Plants and parsons in nineteenth century New South Wales', Historical Records of Australian Science (1980-2) 5(3), pp. 17-32. For more on John Fereday in particular see www.anbg. gov.au/biography/fereday-john.html (accessed 26 June 2020).

112 Vasile, op. cit. (20), p. 14.

113 Secord, op. cit. (8), p. 106. Collecting cryptogams was a particularly tricky undertaking, and one which Hooker described as 'very tiresome'. Quoted in Endersby, op. cit. (3), p. 69.

${ }^{114}$ Daniel Lewis, The Feathery Tribe: Robert Ridgway and the Modern Study of Birds, New Haven, CT: Yale University Press, 2012, pp. 122-44, notes that by the last quarter of the nineteenth century, American ornithologists relied mainly on collectors to do their fieldwork for them.

115 See Lucas and Lucas, op. cit. (90), p. 64.

${ }^{116}$ Henrika Kuklick, 'After Ishmael: the fieldwork tradition and its future', in Akhil Gupta and James Ferguson (eds.), Anthropological Locations: Boundaries and Grounds of a Field, Berkeley: University of California Press, 1997, pp. 47-65, 53.
} 
case) to Europe, they did so using knowledge that was often 'generated in, and permeated by, indigenous presence'. ${ }^{117}$ The part played by indigenous people as guides, pathfinders and interpreters in European voyages of exploration and other collecting activities was sometimes recognized at the time. The handbook of one Victorian naturalist, William Swainson, tersely advised would-be collectors that 'reptiles and serpents are best procured by the natives'. ${ }^{118}$ And this aspect is now increasingly being acknowledged by scholars. ${ }^{119}$ The role of those who travelled 'before the mast'-ordinary sailors and seamen - is also attracting more attention. Londa Schiebinger has pointed out that the collecting activities of voyaging botanists were supported by numerous assistants, without whom such activities would have been impossible. ${ }^{120}$ For example, in his instructions to voyagers in 1696, John Woodward specified in detail how 'the gathering and preserving of insects, shells, plants and minerals etc. may be done by the hands of servants, and that too at their spare and leisure times'. ${ }^{121}$ In short, then, there is a whole cast of relatively unacknowledged agents and actors involved in collecting activities whose contributions to these processes can be resuscitated by focusing on the practicalities of collecting.

In his account, Clarke Abel observed that 'the medical officers of ships of war, and of Indiamen, are especially fitted for the pursuit of natural history'. ${ }^{122}$ The role of the ship's medical officer, particularly in naval vessels, as the de facto resident naturalist on board was prevalent as early as the seventeenth century. It came to be increasingly recognized in the eighteenth and nineteenth centuries. ${ }^{123}$ Indeed, William Harvey was the beneficiary of this phenomenon. He identified the surgeon on board the P\&O steamer Pottinger as a potential source of future specimens. Dr O'Sullivan obliged Harvey by preserving a chimpanzee that had died en route, from India to Singapore: the skull was "cleaned and kept to be sent to R[obert] Ball'. According to Harvey, the surgeon was 'very willing to send any curiosities and has opportunities of getting things between Bombay, Sincapore [sic], and China - if he knew what would be valued'. ${ }^{124}$ Later in the 1850s, Harvey benefited from the collecting of a naval surgeon, receiving specimens from the surgeon of HMS Plumper as it surveyed Vancouver Island and British Columbia. ${ }^{125}$ But Clarke Abel also acknowledged that this interest in science extended beyond the officer class, remarking that he had 'repeatedly seen an ardent curiosity excited by my pursuits in the minds of those

\footnotetext{
${ }^{117}$ Bronwen Douglas, 'Expeditions, encounters, and the praxis of seaborne ethnography: the French voyages of La Pérouse and Freycinet', in Martin Thomas (ed.), Expedition into Empire: Exploratory Journeys and the Making of the Modern World, London: Routledge, 2015, pp. 108-26, 116. For a detailed discussion of the situation in relation to botanical collecting in Australia see Philip Clarke, Aboriginal Plant Collectors: Botanists and Australian Aboriginal People in the Nineteenth Century, Kenthurst: Rosenberg Publishing, 2008.

${ }^{118}$ William Swainson, Taxidermy, Bibliography and Biography, London: Longman, Orme, Brown, Green, and Longmans, and John Taylor, 1840, p. 6. Quoted in Murray, op. cit. (73), p. 117.

${ }^{119}$ Hammel, op. cit. (98), p. 7. See also Kapil Raj, 'Go-betweens, travelers, and cultural translators', in Bernard Lightman (ed.), A Companion to the History of Science, Chichester: Wiley Blackwell, 2016, pp. 39-57; Felix Driver and Lowri Jones, Hidden Histories of Exploration: Researching the RGS-IBG Collections, London: Royal Holloway, University of London, 2009; Shino Konishi, Maria Nugent and Tiffany Shellam (eds.), Indigenous Intermediaries: New Perspectives on Exploration Archives, Canberra: ANU Press, 2015; Michael Bravo, 'Indigenous voyaging, authorship and discovery', in Adriana Craciun and Mary Terrall (eds.), Curious Encounters: Voyaging, Collecting, and Making Knowledge in the Long Eighteenth Century, Toronto: University of Toronto Press, 2019, pp. 71-112.

${ }^{120}$ Schiebinger, op. cit. (45), p. 46.

${ }^{121}$ Woodward, op. cit. (45), p. 16.

${ }^{122}$ Abel, op. cit. (92), p. 26.

${ }^{123}$ John J. Keevil, Christopher Lloyd and Jack L.S. Coulter, Medicine and the Navy, vol. 4: 1815-1900, Edinburgh: Livingstone, 1963, p. 69.

${ }^{124}$ WHH to HHT, 'the feast of St Thomas' [21 December], 1853, TCD, MS 3640/8, emphasis in original.

${ }^{125}$ Hana Oh, 'Connecting the British Pacific: naval surgeons in the mid-nineteenth century Pacific', unpublished D.Phil. thesis, University of Oxford, 2020, p. 187.
} 
whose general habits of life would appear least likely to render them observers of nature'. And he recognized that he was 'indebted to their industry, intelligence and kindness, for the possession of a number of specimens and remarks'. ${ }^{126}$ The collecting of material culture provides an analogous example. Ordinary sailors collected 80 per cent of the objects collected by HMS Mermaid on its survey of Australia. ${ }^{127}$

On land, nineteenth-century European botanists depended on local, often indigenous, help and expertise. In South Africa, Robert Plant trained African staff to collect plants, and when he visited the Seychelles in 1853, he paid the locals who collected shells for him a shilling a day plus a bottle of rum. ${ }^{128}$ James Drummond, the former superintendent of the botanical gardens in Cork, offered an approach to botanical collecting in Western Australia, whence he had emigrated following the closure of the gardens in Cork in 1828. Harvey reported that Drummond's 'habit for years has been to traverse the country in the collecting season with his three ponies and one or two natives, and to live for months together in the bush, shifting his quarters as he exhausts each neighbourhood'. ${ }^{129}$ Harvey's collecting activities relied similarly on local assistance. At Ceylon, for example, a botanizing expedition was assisted by 'a train of 16 coolies to carry our baggage and their own food'. ${ }^{130}$ The labourers carried 'luggage and plants in train'. ${ }^{131}$ At Newcastle, in New South Wales, Harvey 'had the use ... of the harbour-master's boat', with its crew of 'two New Zealanders [Maori] and two South Sea Islanders, capital boatmen'. ${ }^{132}$ Assistance went beyond manual labour. At Trincomalee, Harvey 'hired a plant collector, and sent him today into the jungle for the first time. And if I get anything by it, he will be the finder'. ${ }^{133}$ It is worth noting that this unnamed agent also relied on local help, as he departed on his expedition 'with a coolie to carry his gatherings'. Harvey's dependence was underlined by his feeling that he did not have the 'physical strength to accompany him, as I cannot bear the sun after eight o'clock in the morning. ${ }^{134}$ Later, the 'plant boy' returned with some algae and promised that if Harvey could procure him a boat, he would find more specimens. Harvey was much impressed by the 'collector', introduced to him by Thwaites at Peradeniya: 'so far, I have found him agreeable and clever - and diligent':

He is a Malay. If he continues to give satisfaction I may take him on to Australia. He spoke to me the other day, as if he wished to go to England, so I suppose he has no objection to travel. I find him a great help in the faggery of washing and drying as well as in collecting. ${ }^{135}$

Harvey relied on local help throughout his expedition. In Australia, an aboriginal woman witnessed Harvey collecting on a beach and used her initiative to furnish him with more supplies. After securing a promise of payment from the naturalist, the woman returned half an hour later 'with her apron half full of the shells, and was thankful for sixpence'. ${ }^{136}$

\footnotetext{
${ }^{126}$ Abel, op. cit. (92), p. 26.

${ }^{127}$ Simpson, op. cit. (87), pp. 178 n. 111, 360-2.

${ }^{128}$ McCracken, op. cit. (55), pp. 3-4.

${ }^{129}$ WHH to MCH, 21 April 1854, TCD, MS 3640/15. Drummond's collections were not without their shortcomings, however. See Endersby, op. cit. (3), pp. 67-8.

${ }^{130}$ WHH to RH, 24 October 1853 , TCD, MS 3640/5.

${ }^{131}$ WHH to HHT, 28 September 1853, TCD, MS 3640/3.

132 WHH to HHT, 31 May 1855 , TCD, MS 3640/25.

${ }^{133}$ WHH to William Hooker, [September] 1853, in Ducker, op. cit. (24), p. 63.

${ }^{134}$ WHH to HHT, 14 September 1853, in Fisher, op. cit. (16), p. 251.

${ }^{135}$ WHH to William Hooker, [September] 1853, in Ducker, op. cit. (24), p. 64. Hooker approved of botanists liberating themselves from such dreary work. See Secord, op. cit. (8), p. 110.

${ }^{136}$ Fisher, op. cit. (16), p. 266.
} 
And in Tonga, when Harvey asked for a guide at the 'mission-house', he was 'furnished with a man called Koroe, who climbed trees for parasites, gathered flowers, carried my bundle, and was very agreeable'. ${ }^{137}$

The help afforded by settlers on the spot was invaluable too. ${ }^{138}$ During his time in South Africa in the 1830s, Harvey relied on a variety of non-professional collectors. He forwarded plants to Nathaniel Ward that had been collected by 'Rev. W. Elliot at the Paarl':

This gentleman is now busily working for me. I found him in the midst of bundles of specimens, though the poor man was just getting rid of intermitting [sic] fever, which had been in his family for three months. There's zeal! - I hope to get many good things from him, as he is anxious to find and examine every plant within reach. ${ }^{139}$

And nearly two decades later, Harvey continued to depend on help from local people at every stage of his collecting expedition. Given that Harvey's own publications, such as the Manual of the British Algae (1841) and The Seaside Book (1849), had helped to popularize collecting in the British Isles, it is unsurprising that this interest extended to colonists in the southern hemisphere. The assistance that Harvey received in Western Australia really came into its own. The first comptroller-general of convicts for the colony, Edmund Henderson, evinced 'some taste for natural history pursuits though merely an amateur', for example. ${ }^{140}$ But support came from a range of sources and often from less elevated quarters. At King George's Sound, 'the man who drives the mail cart from here to Swan River' told Harvey about some useful areas to collect. He was, Harvey observed approvingly, 'fond of picking up flowers, insects etc. and quite an observant man'; in short, the ideal local assistant and agent on the ground. ${ }^{141}$ At the Swan river, where Harvey collected vast quantities of seaweed, he relied on the kindness of the people here' to advance his activities. He had 'the use of some empty rooms at the public offices, to dry my plants, the use of the pilot boat of 6 tons with two men, for dredging - the loan of a dredge, sea rake, and ropes for fishing'. ${ }^{142}$ Access to 'a good boat and crew without cost - another favourable circumstance' - was provided by 'my kind friend Mr Clifton, Superintendent of water police'. ${ }^{143}$

George Clifton took 'much interest' in Harvey's work, and his contributions were later acknowledged in Harvey's important five-volume study of Australian seaweeds, Phycologia Australica. ${ }^{144}$ Clifton was helpful in gathering and preserving the specimens collected by Harvey at Rottenest Island and elsewhere in Western Australia, before his departure for Melbourne. Harvey packed nearly ten thousand specimens collected at King George's Sound and its environs in a 'zinc-lined box measuring $36 \times 20 \times 20$ inches to be shipped to London'. The box was left with Clifton, who was now, according to Harvey, 'a devoted collector of seaweeds, having been severely bitten by me'. Not everyone in the Clifton household approved of George's new-found passion for natural history, however: 'Poor Mrs. C says (resignedly) that she despairs of ever having the house tidy again and hopes he wont tear up all the baby's linen for rags. He has already laid violent hands

\footnotetext{
${ }^{137}$ Fisher, op. cit. (16), p. 309.

${ }^{138}$ For more on the interest in natural history among colonists in New South Wales in particular, see Anne Coote, "'Pray write me a list of Species ... that will pay me best": the business and culture of natural history collecting in mid-nineteenth-century New South Wales', History Australia (2014) 11(2), pp. 80-100, 81.

139 WHH to NBW, 20 April 1838, in Fisher, op. cit. (16), p. 104.

${ }^{140}$ WHH to MCH, 21 April 1854, TCD, MS 3640/15.

${ }^{141}$ WHH to MCH, 10 January 1854 , TCD, MS 3640/9.

${ }^{142}$ WHH to HHT, 13 April 1854, TCD, MS 3640/14.

${ }^{143}$ WHH to HHT, 16 May 1854 , TCD, MS 3640/16.

${ }^{144}$ WHH to HHT, 16 May 1854, TCD, MS 3640/16. For more on Clifton see Desmond, op. cit. (96), p. 154.
} 
on his own night shirts! ${ }^{145}$ The processes involved in collecting and drying seaweeds were complex, requiring skill and attention to detail. It is perhaps unsurprising, then, that the first volume of Phycologia Australica was dedicated to Clifton, whom Harvey described as 'an acute observer and successful collector of algae', 'in pleasant memory of our boating and dredging excursions and as a grateful acknowledgement for the liberal supplies of well-selected specimens'. ${ }^{146}$ The preface to the fifth volume similarly lauded Clifton as having provided 'some thousands of beautifully preserved specimens, including many species collected by no one else'. ${ }^{147}$

Harvey continued to benefit from the help of local settlers as he worked his way eastwards. At Phillip Island, about ninety miles south-east of Melbourne, he was particularly complimentary about the McHaffie family, declaring that 'nothing could exceed their kindness to me, the whole time I was with them'. During that fortnight, he told his sister, he 'had the use of everything and all the available room and liberty to have my wet papers on lines all round the sitting room till it looked like one of R. Webb's drying rooms!' And this assistance paid off: 'I have made a very good collection of algae at the island and discovered one very curious new genus. ${ }^{148}$ Later in the journey, at Van Diemen's Land, John Fereday proved to be a practical assistant as well as an armchair amateur of natural history, volunteering himself as an 'ally and assistant while I remain here':

And as he has a boat a dredge and horse and cart (all expensive things to hire) and seems to have plenty of time on his hands we are likely to be pretty constant companions. Besides this he undertakes to save for me in future any novelty he may find and as he and his wife and daughters are constantly making sea shore rambles in favourable weather he is likely to do much for us. ${ }^{149}$

The Reverend Fereday was a friend indeed, giving Harvey 'the greatest assistance in my researches here which owe much of their successes to his kind aid. Having a boat, a thorough knowledge of the localities and a taste for collecting he places all at my service and whenever I want specimens I have only to cross the green and report that my stock is used up and then we are off for more'. ${ }^{150}$ And for her help with the complicated process of "'laying out" and drying the tubs-full of delicate Algae', Harvey acknowledged Susan Fereday. $^{151}$

\section{Conclusion}

Casting the net beyond men of science like William Harvey underlines the fact that collecting natural-history specimens in the nineteenth century depended on many people and involved a complex array of interrelated activities: identifying, recognizing, locating, catching, collecting, gathering, carrying, transporting, transferring, shipping, preserving, analysing, interpreting, displaying. Success was always contingent and never inevitable. Logistics and organization were fundamental to a successful collecting journey. We should not, David Igler cautions, 'underestimate the significance of inventiveness, luck, circumstance, and genuine delight in studying their surroundings' that affected the work of naturalists. ${ }^{152}$ Empirical knowledge and material resources were crucial. The letters, diaries,

\footnotetext{
${ }^{145}$ WHH to HHT, 3 August 1854, TCD, MS 3640/17a.

${ }^{146}$ Harvey, op. cit. (23), vol. 1, dedication.

${ }^{147}$ Harvey, op. cit. (23), vol. 5, p. v.

${ }^{148}$ WHH to HHT, 29 December 1854, in Ducker, op. cit. (24), p. 172.

${ }^{149}$ WHH to HHT, 15 January 1855, TCD, MS 3640/20.

${ }^{150}$ WHH to HHT, 9 February 1855, in Ducker, op. cit. (24), p. 182.

${ }^{151}$ Harvey, op. cit. (23), vol. 5, p. vi.

${ }^{152}$ Igler, op. cit. (5), p. 72.
} 
journals and memoirs of nineteenth-century collectors yield a rich crop of evidence, illuminating the practical obstacles and challenges they faced, as well as the people they depended upon. As historians increasingly turn to these aspects of collecting history, the example of William Henry Harvey has much to tell us. His hybrid status as a herbarium curator and professor of botany on the one hand, and an independent collector and self-defined 'amateur' on the other, situates him and his collecting experiences at the heart of the complex array of considerations and contingencies affecting nineteenthcentury natural-history collecting. Reconstructing Harvey's varied experiences on his cryptogamic expedition to Australia helps to illuminate these complexities, paying attention to activities that were routine and commonplace to contemporary travellers but crucial to present-day historians in attempting to understand and interpret these collecting journeys and the kinds of material knowledge they represent.

Acknowledgements. I am grateful to the staff of the Department of Manuscripts and Archives, Trinity College Dublin, for their help and assistance. I would particularly like to thank Amanda Rees and Trish Hatton, as well as the journal's anonymous reviewers, for their generous and constructive feedback. Thanks also to Rohan Deb Roy, Sarah Longair and Patience Schell for their valuable suggestions and comments on earlier versions of this work.

Cite this article: McAleer J (2022). 'The troubles of collecting': William Henry Harvey and the practicalities of natural-history collecting in Britain's nineteenth-century world. The British Journal for the History of Science 55, 81-100. https://doi.org/10.1017/S0007087421000704 